\title{
Enhancement and Stabilization of the Moiten Carbonate Fuel Cell Performance by Optimization of Electrode Pore Distributions
}

\author{
Yoshio IWASE, Hideo OKADA, Satoshi KUROE, Shigenori MiTsushima \\ and Masato TAKEUCHI*
}

Received September 28, 1992 ; Accepted July 16, 1993

\begin{abstract}
The electrode performance of the molten carbonate fuel cells depends on the electrolyte occupation of pores. Therefore, we have tried to control the electrolyte occupation of anode and cathode pores within appropriate ranges by optimizing the anode and cathode pore distributions.

The mean pore diameter of cathode was enlarged to circa 8 um compared that of anode of circa 5 um, which enhanced and stabilized the cell performance. Cell voltages at $150 \mathrm{~mA} / \mathrm{cm}^{2}$ were maintained above $0.8 \mathrm{~V}$ for more than $5000 \mathrm{~h}$.
\end{abstract}

\section{Introduction}

Recently, advanced, environment-friendly electric power systems are receiving an attracting attention. The molten carbonate fuel cell is expected as a new clean electric pover plant system which provides high energy conversion efficiency over $45 \%$ coupled with low emissions of NOx and SOx. Research and development on this fuel cell is carried on in the US, Europes and Japan. The electric power output level has reached $100 \mathrm{~kW}$, but further enhancement and stabilization of the cell performance are required for practical use. In particular, the electrodes must be improved. Electrode performance had been found to be affected by electrolyte occupation of cathode ${ }^{2)}$ 2) and anode ${ }^{3) 4}$ pores. Consideration was also given to how electrode structural factors, for example, porosity, pore distribution and thickness, affect cell performance ${ }^{5-8)}$, and suitable ranges of these factors were identified ${ }^{5)}$. It is necessary to control the electrolyte distribution in a cell in order to get a high performance and long term durability. For molten carbonate fuel cells, there is no useful material to regulate the electrode wettability. Optimizing the electrode pore distributions should provide better electro -lyte control in. the cells than before. Therefore, we began to custorize the electrode pore distributions.

Hitachi Research Laboratory, Hitachi, Ltd. (1-1, Omika-cho 7-chome, Hitachi-shi, Ibaraki-ken, 319-12)

Key Words : Fuel Cell, Molten Carbonate, Anode, Cathode, Pore Distribution

\section{Experimental}

Nickel oxide plate containing 2 atom $\%$ silver was used as a cathode. It was fabri -cated by impregnation of a sintered porous nickel plate with a silver nitrate solution, followed by calcination in air at 1073K for

$0.5 \mathrm{~h}$. A porous nickel plate containing 5 atons cobalt, and 10 aton $\$$ magnesiun or 5 aton $\$$ aluminium was used as an anode. At first, a sintered porous nickel plate was impregnated with cobalt nitrate solution. Then the plate was calcinated in air at $723 \mathrm{~K}$ for $4.0 \mathrm{~h}$, and recalcinated in $70 \mathrm{SH}_{2}-30 \mathrm{SCO}_{2}$ at $923 \mathrm{~K}$ for $0.5 \mathrm{~h}$. The porous nickel plate was also impregnated vith magnesium nitrate solution by the sane wethod as for cobalt. The electrode area was $100 \mathrm{~cm}^{2}$.

An aluminizing treatment was applied to the surface of the wet sealing part of the electrode holders for anticorrosion, and also to the anode without magnesia for the restraint on the anode sintering and creep during the cell operation'?

The doctor blade method was used to prepare the electrolyte watrix. The matrix was impregnated with a mixture of $\mathrm{Li}_{2} \mathrm{CO}_{3} / \mathrm{K}_{2} \mathrm{CO}_{3}$ ( 62: 38 mole\%) in a cell while being heated. The natrix area was $196 \mathrm{~cm}^{2}$, with a thickness of about $1.3 \mathrm{~mm}$ and porosity of $49.0 \%$.

Long term endurance tests of the lab scale cells (effective electrode area: $100 \mathrm{cll}^{2}$ ) vere carried out under the following conditions. Operating temperature was $650^{\circ} \mathrm{C}$, the anode gas composition $80 \mathrm{xH}_{\mathrm{z}}-20 \% \mathrm{CO}_{2}\left(10 \mathrm{xH}_{2} \mathrm{O}\right)$, and the cathode gas composition was $70 \% \mathrm{Air}-30 \mathrm{SCO}_{2}$. The 
utilizations of both reaction gases were $40 \%$ at $150 \mathrm{~mA} / \mathrm{cmil}^{2}$. The cell structure is depicted in Fig.1. Simple inprovement of the test apparatus and cell structure enabled us to supply the electrolyte during the cell operation. The electrolyte, packed in two alumina tubes, was transported to the electrolyte plate surface of the wet sealing part directly, and its supply was controlled during the cell operation, at $650^{\circ} \mathrm{C}$.

The electrolyte occupations of both electrodes were evaluated by two methods. The first was a calculation using pore distri -bution data, and the second was the measuring weight losses of the electrodes which were saturated with distilled water and then dried. Figure 2 shows the cell structure used for the latter. The electrodes filled with water were placed on top of each other without the electrolyte plate and were held between corrugated, stainless steel plates. The electrodes were weighed occasionally as the cell was being slowly dried. The water occupations of both electrodes at the same time were calculated using the measured weights, and the time dependences of occupation values were evaluated.
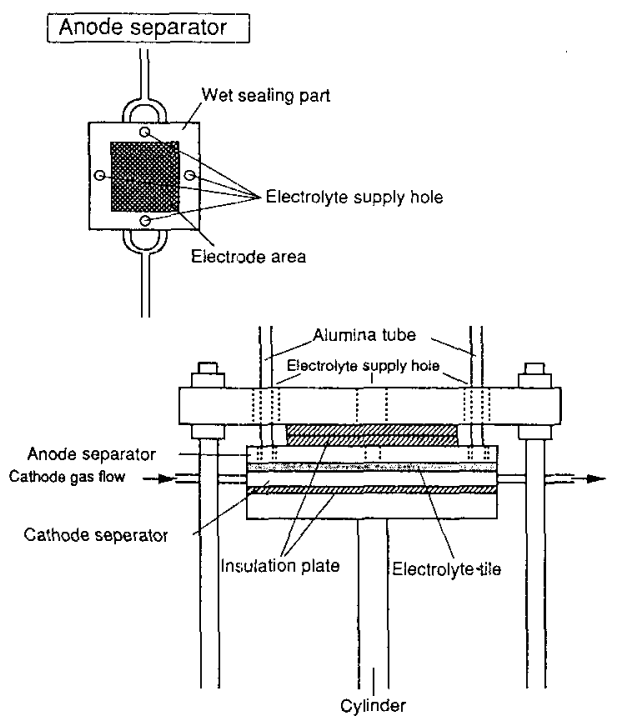

Fig.1 Electrolyte supply cell structure

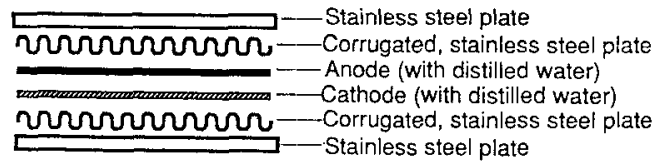

Fig. 2 Quasi-cell composition for the evaluation of electrode occupations
Results and Discussion

We have tested several hundreds of lab scale cells for the molten carbonate fuel cell, but performance had been insufficient. The average cell voltage initially was over $0.8 \mathrm{~V}$ at $150 \mathrm{~mA} / \mathrm{cll}^{2}$, but it dropped to $0.6-0.65 \mathrm{~V}$ level before 1000 hours operation.

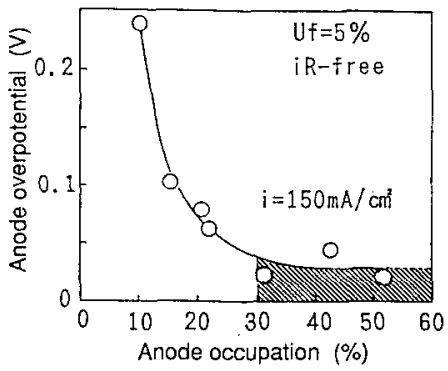

Fig.3 Electrolyte occupation dependence of the anode overpotential

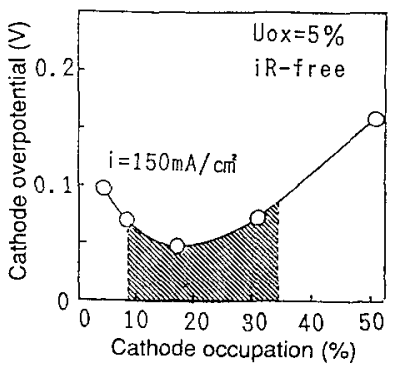

Fig.4 Electrolyte occupation dependence of the cathde overpotential

Figure 3 shows anode overpotential dependence on the electrolyte occupation of anode pores, wile the cathode case is shown in Fig.4. Anode iR-free overvoltage at $150 \mathrm{~mA} / \mathrm{cal}^{2}$ decreases with increasing anode electrolyte occupation. The value was less than $50 \mathrm{mV}$ above $30 \%$ occupation. On the other hand, cathode overpotential had its minimun value at about 20 $\%$ occupation. The suitable range for cathode occupation seems to be $10-35 \%$, because the cathode overpotential was less than $80 \mathrm{mV}$ in this range. If we want to get and keep a higher cell voltage, electrolyte occupation

Table 1 Effects of the occupation change on the cell voltage

\begin{tabular}{|c|c|c|c|c|c|c|}
\hline & \multicolumn{2}{|c|}{ Initial value } & \multicolumn{2}{|c|}{$\begin{array}{l}\text { At the beginning } \\
50-100 \mathrm{~h}\end{array}$} & \multicolumn{2}{|c|}{$\begin{array}{l}\text { After operation } \\
\text { over } 100 \mathrm{~h}\end{array}$} \\
\hline & $\begin{array}{c}\text { Occupalion } \\
(\mathbf{x})\end{array}$ & $\begin{array}{c}\text { Overvoltage } \\
(\mathrm{mV})\end{array}$ & $\begin{array}{c}\text { Occupation } \\
(x)\end{array}$ & ${ }_{(\mathrm{mV})}^{\text {Overvoltage }}$ & Oocupation & $\begin{array}{c}\text { Ovenoltage } \\
\text { (my }\end{array}$ \\
\hline Anode & 40 & 90 & - & - & 12 & 220 \\
\hline Cathode & 20 & 50 & - & - & 45 & 150 \\
\hline $\begin{array}{l}\text { Cell voltage } \\
\text { (calculated) }\end{array}$ & \multicolumn{2}{|c|}{$0.86 \mathrm{~V}$} & \multicolumn{2}{|c|}{ - } & \multicolumn{2}{|c|}{$0.63 \mathrm{~V}$} \\
\hline $\begin{array}{l}\text { Cell voltage } \\
\text { (measured) }\end{array}$ & \multicolumn{2}{|r|}{ - } & \multicolumn{2}{|c|}{$0.75-0.85 \mathrm{~V}$} & \multicolumn{2}{|c|}{$0.6-0.65 \mathrm{~V}$} \\
\hline
\end{tabular}


must be kept in the above ranges throughout the cell operation. The drop in cell performance after 1000 hours operation was probably due to deviation from these ranges. Table 1 shows the relationships between occupation, overpotential and cell voltage. If the electrode occupations were determined, the cell voltage could be estimated by the results of Figs 3 and 4 . The electrode occupations were fixed at the initial value of $60 \%$ for the anode and $20 \%$ for the cathode. If these amounts of electrolyte remain in the electrode pores, the expected cell voltage was $0.86 \mathrm{~V}$ at $150 \mathrm{nA} / \mathrm{cm}^{2}$. But the measured values were lower than this. So after operation, electrode occupations were analyzed, and found to be about $12 \%$ for the anode and $45 \%$ for the cathode. The increase of cathode occupation means that the electrolyte movement from anode to cathode had happened in the cell. The calculated cell voltage was then $0.63 \mathrm{~V}$, which was in the range of the measured values, $0.6-$

$0.65 \mathrm{~V}$. From these results, it was concluded that occupation changes in the electrodes were the nain reasons for degradation of the cell performance, because the total electrolyte anount in a cell was found out to be much the same. In other words, the electrolyte movement anong cell components affected the cell performance.

Electrolyte distribution in a cell may be controlled by the electrolyte retaining force balance among porous cell components. The next equation expresses the relationship between the retaining force $\mathrm{P}$ and pore dianeter $\mathrm{D}$.

$$
\begin{gathered}
\mathrm{P}=4 \sigma \cdot \cos \theta / \mathrm{D}----(1) \\
\sigma: \text { surface tension, } \\
\theta: \text { contact angle }
\end{gathered}
$$

Retaining force $P$ is inversely proportional to the pore diameter $D$, therefore smaller pores have stronger liquid (electrolyte) retaining force. Thus, the electrolyte balance among porous cell components is thought to be controlled by their pore distribution. Pore size distributions of anode, cathode and electrolyte plate were measured by a porosinetry method. Figure 5 shows the pore distribution relationship of our former cell components.

The accumulative occupied pore volumes were calculated from measured pore distributions, geometric volumes and porosities of those components, according to the assumption that electrolyte fills winuter pores first, then the bigger ones. In order to simplify the calculation, $\cos \theta=1\left(\theta=0^{\circ}\right)$ was applied to all

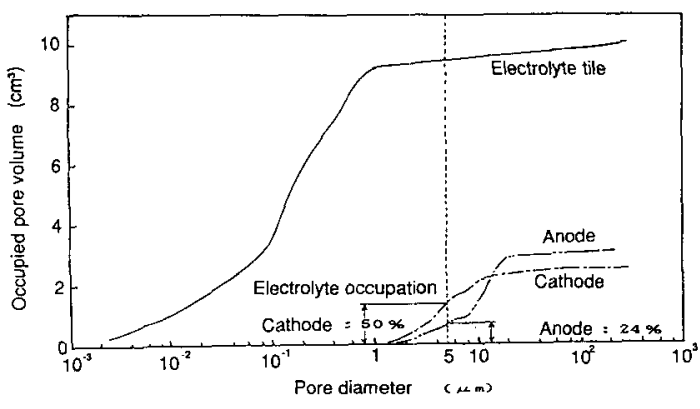

Fig.5 Pore distributions of cell components and the electrolyte distribution in a cell

components. Therefore, Fig. 5 is an estimation of electrolyte distribution in a cell. For example, when the electrolyte occupies pores with a diameter smaller than $5 \mu \mathrm{m}$, anode and cathode occupations are judised as $24 \%$ and $50 \%$ respectively by taking into account the volume ratio to the accumulative occupied pore volume.

Calculations of anode and cathode occupations for each diameter give Fig.6. The [a]-type curve means that the cathode occupation is always larger than the anode occupation, since the cathode pore diameter is smaller than the anode one. The closed circle

(C) indicates the fixed values of electrode occupations and the open circle (O) indicates the analyzed occupation values (in Table 1) of the [a]-type cell. Fron results on
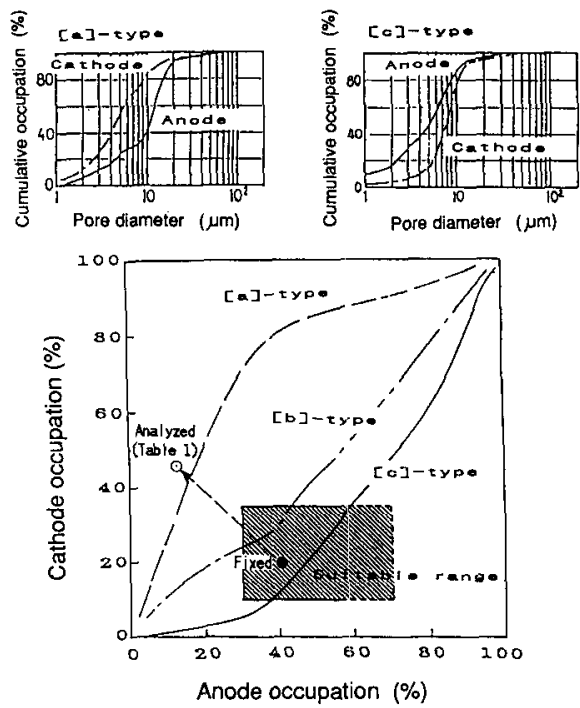

Fig.6 Relationships between anode and cathode pore distributions and occupationds 
occupation effects on anode and cathode perfornances (Figs 3 and 4), the suitable occupation range was estimated as marked in Fig. 6. The expected curve must cross the suitable occupation range and the curve length in the suitable occupation range should be longer ([a] $\Rightarrow[b] \Rightarrow[c])$, to ensure that the changeable electrolyte amount in the suitable occupation range is large and the cell performance is more stable with less effect from electrolyte decrease. Therefore, we decided to change the relationship between anode and cathode pore distributions.

The electrode performance is also affected by

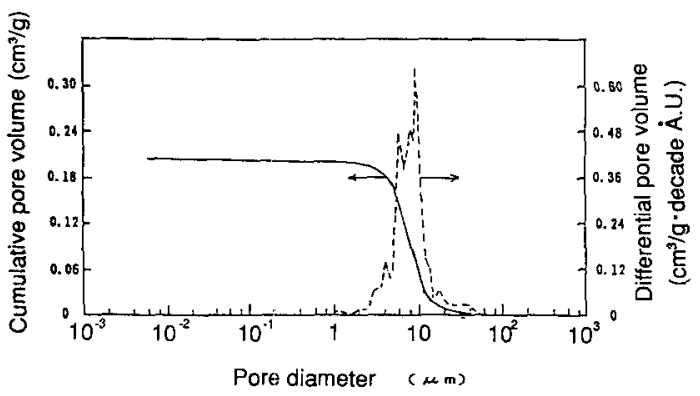

Fig.7 Pore ditribution of the improved cathode

the micro pore structure. Sufficient gas diffusibility must be obtained. We assumed that the cathode pore enlargenent was necessary and it would be the best way to adjust the electrode occupations. In order to inprove cathode pore distribution, production process study was carried out. And an acceptable cathode was made. Figure 7 shows the developed cathode pore distribution. The mean pore diameter value of developed cathode was about $8 \mu \mathrm{m}$, which was about $3 \mu \mathrm{m}$ larger than the original, [a]-type, cathode. We selected the suitable anode to fit the improved cathode pore distribution in order to adjust both electrode occupations. In Fig.6, the relationship curve between the developed cathode and anode occupations was the [c]-type, wich had the greatest length in the suitable occupation range. A sample with [b]-type, i.e. anode and cathode pore distributions were almost the same, was also prepared to allow comparison of the time dependence of the cell performance.

Figure 8 shows typical examples of cell performance. At the beginning of operation (i), the highest cell voltages were recorded, these values were about $0.85 \mathrm{~V}$ at $150 \mathrm{nA} / \mathrm{col}$. However, at about 1000 hours (ii) and about 2000 hours (iii), differences in cell voltages

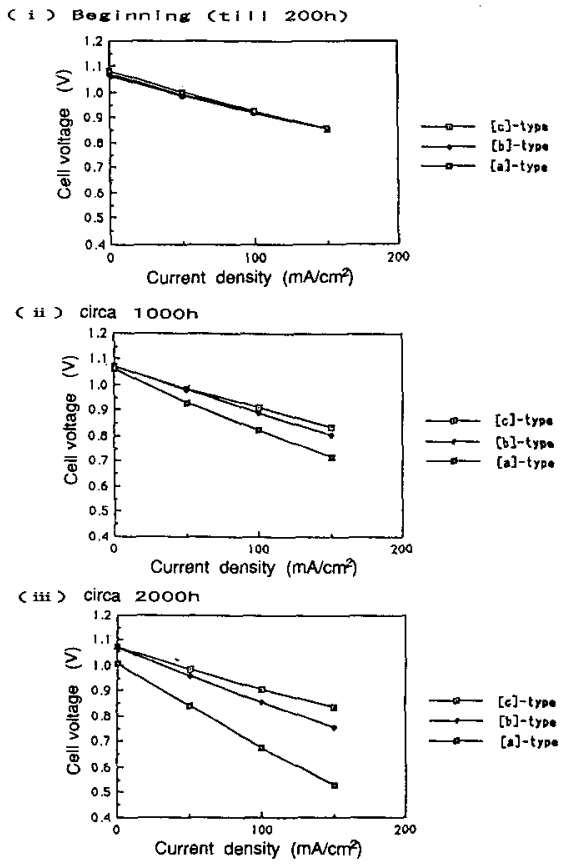

Fig.8 Differences in cell performance for three type cells

between these three types of the cells occured gradually. There are wany causes for cell voltage drop and the main ones were listed below.

(1) Increase of electric resistance due to stainless steel corrosion.

(2) Drop in anode reaction gas diffusibility and increase in contact resistance due to anode creep.

(3) Increase in ionic resistance due to electrolyte loss.

Reasons (1)-(3) are common phenomena for the three type cells.

In this comparison test, the wain reason was considered as:

(4) Increase of reaction resistance due to unsuitable occupation of electrodes.

This consideration was based on results of [a] -type in Table 1. Although electrolyte loss occurred during the operation, the iR-value could be calculated using the measured cell resistance. The cell voltage drop was several times larger than the increased $i R$-values. The [c]-type cell does not show any conspicuous drop, therefore, reason (4) was eliminated by custonizing the pore distribution between the cathode and anode, in case of [c]-type cell. 


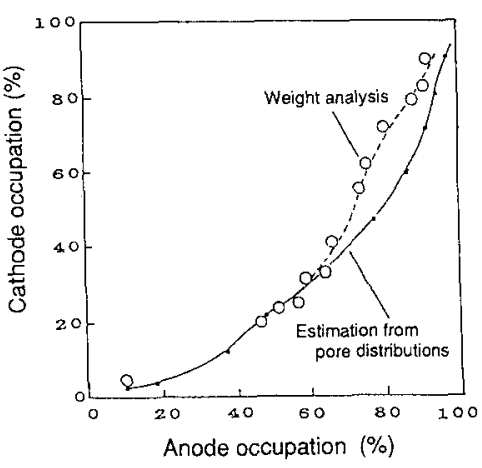

Fig.9 Confirmation of electrolyte occupation balance in both electrodes

It was necessary to prove that electrolyte occupation in electrodes was balanced. The change in occupation of the electrodes was examined by the previously mentioned method. The results are shown in Fig.9. The circles show the values obtained by the simple method in which weight changes were measured during drying. The solid line is the calculated occupations from pore distributions of the porosimetry. Both results agreed well over almost the whole range, especially at low occupation. Thus, agreement confirms the validity of the assumption in calculating occupations from pore distributions was confirmed with comparing, the experimental results of measuring weight changes. Therefore, it was concluded that the occupation balance can be estimated by these methods.

Long-term endurance tests of lab scale cells are in progress now. Figure 10 is the representative data from them. The cell voltage was about $0.85 \mathrm{~V}$ at $150 \mathrm{~mA} / \mathrm{d}$ initially and stays above $0.8 \mathrm{~V}$ after more than 5000 hours. Electrolyte supply of a small amount (about $1 \mathrm{~g}$ ) was done almost every thousand hours. This keeps the cell voltage higher, because the ionic resistance was kept lower (than $0.4 \mathrm{l} \cdot \mathrm{d}$ ) and the reaction resistance was also kept lower by adjustment of electrolyte occupations. The degradation ratios of cell voltage surpass our target value, $10 \mathrm{nV} / 1000 \mathrm{~h}(1.0 \% /$ $1000 \mathrm{~h})$. Our target of operation time is more than 15000 hours. A cell voltage drop depending on the increase of iR-value has not been observed yet. Therefore, if we could carry out the appropriate control of the electrode occupations, the operation time could reach 15000 hours.
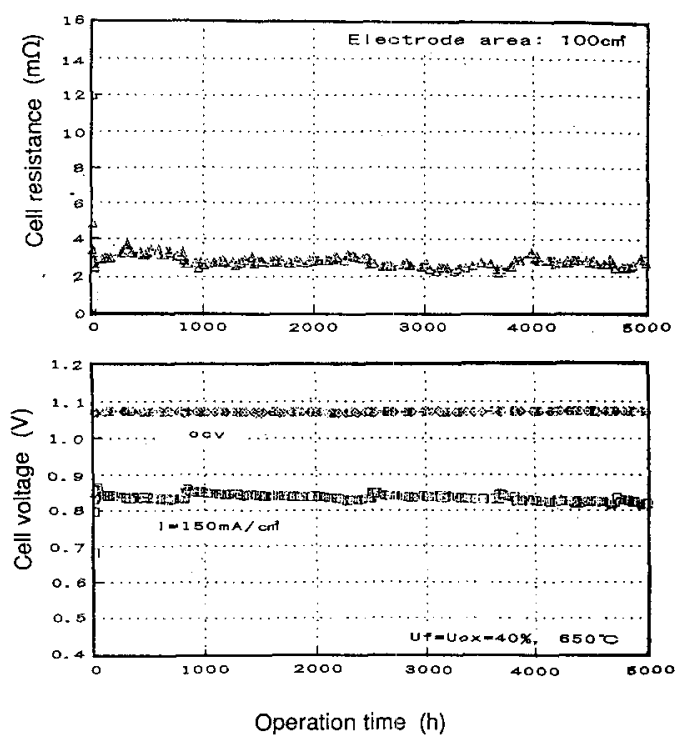

Fig.10 Time dependences of the cell voltage and resistance

\section{Conclusion}

(1) Electrolyte occupation of the anode and cathode during operation could be estimated by a relationship for electrode pore distributions. (2) In long-term endurance tests of lab scale cells using an improved cathode, the cell voltages were kept above $0.8 \mathrm{~V}$ at $150 \mathrm{~mA} / \mathrm{al}$ for wore than 5000 hours.

(3) The cell voltage drop before 1000 hours operation could be prevented by the optini -zation the pore distribution relationship and ensuring an adequate electrolyte supply.

\section{Achnowledgement}

Ve would like to express our appreciation to the Nev Energy and Industrial Technology Development Organization (NEDO) for support of this work.

\section{References}

1) H. R. Kunz, L. J. Bregoli and S. T. Szynanski; J. Electrochem. Soc., 131, 2815 (1984)

2) Y. Iwase, H. Takeuchi, H. Okada and Y. Hishinuma; Ext.Abstr., 87-2, 287-288

( Electrochem. Soc., Honolulu, 1987 )

3) Y. Ivase, S. Kurce, H. Okada, K. Ivanoto and K. Takeuchi; Ext.Abstr., 89-2, 135

( Electrochem. Soc., Thollywood, Florida, 1989 )

4) J. Niikura, K. Hatoh, N. Taniguchi, T. Gamo and T. Iraki; Denki Kagaku., 58, 232 (1990) 
5) Y. Iwase, S. Kuroe, H. Okada, M.Takeuchi and S. Nishimura; Ext..Abstr., 1-37

( International Society of Electrochenistry 42nd Meeting, Montreux, Switzerland, 1991 )

6) 0. Lanzi and U. Landau; J. Electroches. Soc., 137, 585 (1990)
7) C. Y. Yuh and J. R, Selman; J. Electrochem. Soc., 131, 2062 (1984)

8) G. Vilemski; J. Electrochen. Soc., 130, 117 (1984)

9) H. Okada, Y. Iwase, M. Takeuchi and S. Nishimura; Denki Kagaku., 60, 785 (1992) 